\title{
Tumor Microenvironment and Differential Responses to Therapy
}

\author{
Eishu Hirata ${ }^{1}$ and Erik Sahai ${ }^{2}$ \\ ${ }^{1}$ Department of Oncologic Pathology, Kanazawa Medical University, Ishikawa 920-0293, Japan \\ ${ }^{2}$ Tumor Cell Biology Laboratory, Francis Crick Institute, London WC2A 3LY, United Kingdom \\ Correspondence: ehirata@kanazawa-med.ac.jp; erik.sahai@crick.ac.uk
}

Cancer evolution plays a key role in both the development of tumors and their response to therapy. Like all evolutionary processes, tumor evolution is shaped by the environment. In tumors, this consists of a complex mixture of nontransformed cell types and extracellular matrix. Chemotherapy or radiotherapy imposes further strong selective pressures on cancer cells during cancer treatment. Here, we review how different components of the tumor microenvironment can modulate the response to chemo- and radiotherapy. We further describe how therapeutic strategies directly alter the composition, or function, of the tumor microenvironment, thereby further altering the selective pressures to which cancer cells are exposed. Last, we explore the consequences of these interactions for therapy outcomes and how to exploit our increasing understanding of the tumor microenvironment for therapeutic benefit.

Colid tumors contain a complex mixture of Ononcancerous cell types and matrix components. Collectively, this is referred to as the tumor microenvironment or tumor stroma. The microenvironment plays a critical role in many aspects of tumorigenesis. It generates the tumor vasculature and it is highly implicated in the progression to metastasis. More recently, it has become clear that the tumor microenvironment affects the response to therapies. Further, modulating the tumor stroma may improve the efficacy of existing therapies and could present new opportunities for therapeutic targeting. In this article, we introduce the key features of the tumor microenvironment and then discuss how they influence the selective pressures on cancer cells during targeted, chemo- and radiotherapy.

\section{COMPOSITION OF TUMOR MICROENVIRONMENT}

Tumors contain various noncancerous cells including fibroblasts, vascular endothelial cells, and immune cells, including T-cells, macrophages, and neutrophils (Fig. 1) (Hanahan and Coussens 2012). In many cases, organ-specific interstitial cells are also present, for example, osteoblasts in bone tissue and astrocytes in the central nervous system. Collectively, these cells are often termed the tumor stroma and, together with factors such as the extracellular matrix, oxygen levels, and $\mathrm{pH}$, they make up the tumor microenvironment. Because of space constraints, we will only briefly outline the role of stromal cells here. Endothelial cells form the

Editors: Charles Swanton, Alberto Bardelli, Kornelia Polyak, Sohrab Shah, and Trevor A. Graham

Additional Perspectives on Cancer Evolution available at www.perspectivesinmedicine.org

Copyright (C) 2017 Cold Spring Harbor Laboratory Press; all rights reserved; doi: 10.1101/cshperspect.a026781

Cite this article as Cold Spring Harb Perspect Med 2017;7:a026781 
E. Hirata and E. Sahai

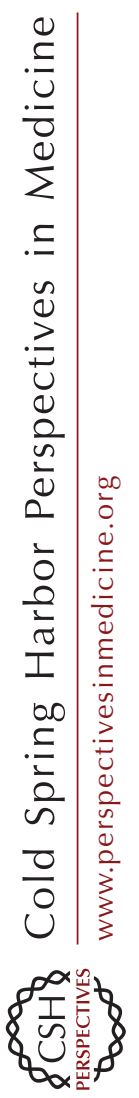

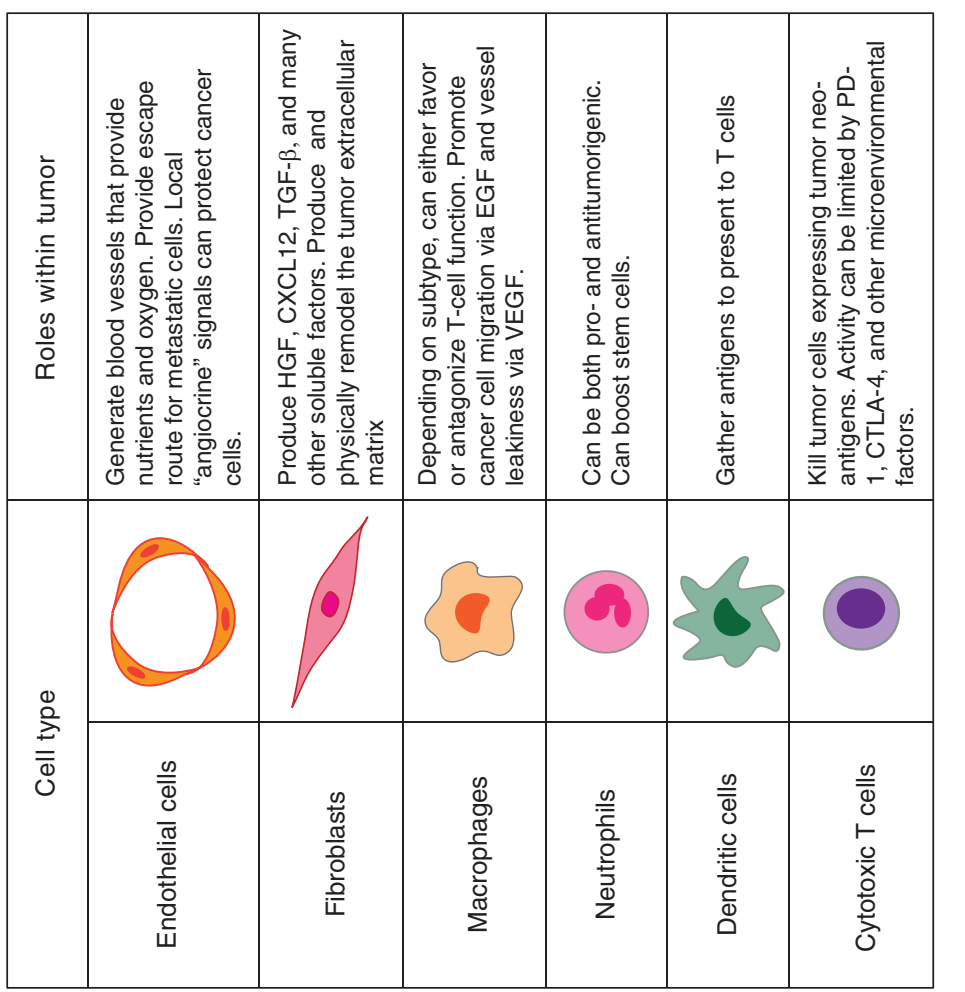

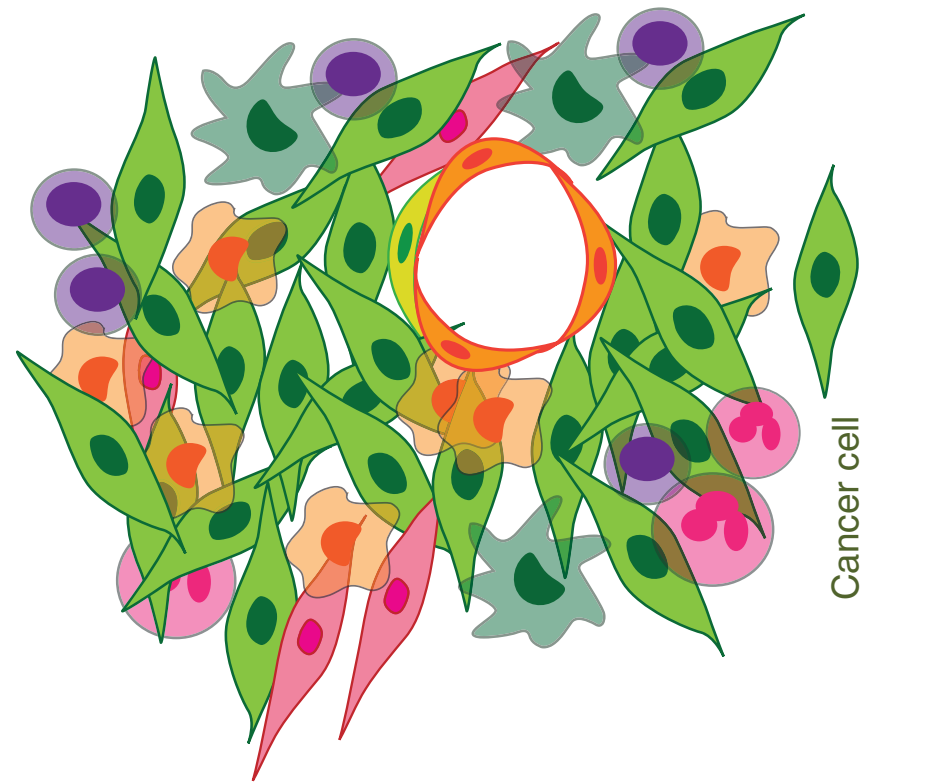

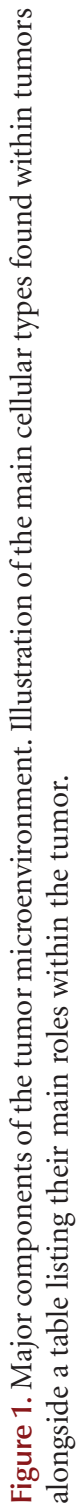


tumor blood vessels and are critical for the delivery of oxygen, nutrients, and drugs to the tumor. Further, they provide an exit route for metabolic waste products and metastatic cancer cells (Reymond et al. 2013). Unlike normal vasculature, tumor vessels are often disorganized leading to local variations in tumor oxygenation and other environmental factors (Harney et al. 2015; Eales et al. 2016). Switching from oxidative phosphorylation to glycolysis is considered to be one of the adaptation strategies of cancer cells to survive in hypoxic conditions (Gatenby and Gillies 2004), although it also works advantageously to produce nucleic acids and nicotinamide adenine dinucleotide phosphate (NADPH) for cell proliferation (Vander Heiden et al. 2009). A byproduct of this is increased lactate levels and therefore lower extracellular $\mathrm{pH}$ can be a feature of tumors (Damaghi et al. 2015).

Cells from both the innate and adaptive immune system are found within the tumors (Hanahan and Coussens 2012). The adaptive immune system can be capable of recognizing tumor cells as "not normal" and $\mathrm{CD}^{+}$cytotoxic T lymphocytes (CTLs) can target them for killing, a process called tumor immune-surveillance (Grivennikov et al. 2010). It is increasingly appreciated that overcoming immune surveillance is a critical part of tumorigenesis (Mittal et al. 2014) and reactivating the process by suppressing "checkpoints" that limit T-cell function is a potent anticancer strategy (Melero et al. 2015; Miller and Sadelain 2015). Innate immune cells, including macrophages and neutrophils are recruited into tumors by similar mechanisms to those that attract them to wounds. They can be both anti- and protumorigenic and cross talk extensively with endothelial cells and the innate immune system (Qian and Pollard 2010). Fibroblastic cells, including resident tissue fibroblasts, pericytes, and mesenchymal stem cells can become activated in tumors. Activated fibroblasts, termed cancerassociated fibroblasts (CAFs), produce and remodel much of the extracellular matrix within tumors (Bhowmick et al. 2004; Kalluri and Zeisberg 2006; Hanahan and Coussens 2012). This can often lead to elevated levels of tissue stiffness in tumors (Levental et al. 2009). CAFs are generally proinvasive and proangiogenic (Madar et al. 2013), although recent evidence shows that they are not universally protumorigenic (Ozdemir et al. 2014; Rhim et al. 2014). Readers are directed to several excellent reviews describe the various components of the tumor microenvironment in detail (Joyce and Pollard 2009; Hanahan and Weinberg 2011; Hanahan and Coussens 2012; McAllister and Weinberg 2014).

To summarize a large body of work, cancer cells and stromal cells can interact in ways that may either favor or hinder tumor progression (Fig. 2). These environmental influences significantly shape tumor evolution. Cancer cells are under selective pressure to maximally exploit favorable microenvironmental conditions and overcome unfavorable ones. The former situation is exemplified by the gain of chemokine receptor expression in various carcinomas. The tumor microenvironment can often contain high levels of chemokines, such as $\mathrm{C}-\mathrm{X}-\mathrm{C}$ chemokine ligand (CXCL) 12/stromal derived factor (SDF) 1 (Orimo et al. 2005). The availability of CXCL12 then means that cancer cells expressing the relevant receptor, $\mathrm{C}-\mathrm{X}-\mathrm{C}$ motif chemokine receptor (CXCR) 4, will be at an advantage. Indeed, high levels of CXCR4 expression are associated with high CXCL12 levels in the primary tumor and metastasis to tissues with high CXCL12 levels (Zhang et al. 2013). Conversely, The gain of immune-suppressive molecules, such as programmed death ligand 1 (PD-L1), can lead to cancer cells overcoming the presence of CTLs that express PD-1 in the tumor microenvironment (Iwai et al. 2002). In addition, there is selective pressure for cancer cells to gain traits that promote the recruitment of protumorigenic stroma. This is perhaps best exemplified by the gain-of-expression of the proangiogenic ligands by cancer cells (Carmeliet and Jain 2000).

Variations in physical factors, such as tissue stiffness, matrix geometry, and electromagnetic fields are also features of the tumor microenvironment. For example, stiffened extracellular matrix prepared by CAFs enhances integrinmediated mechanotransduction related signals, which strongly support cancer cell survival, proliferation, and invasion (Paszek et al. 2005; Butcher et al. 2009; Sulzmaier et al. 2014). Elec- 
E. Hirata and E. Sahai

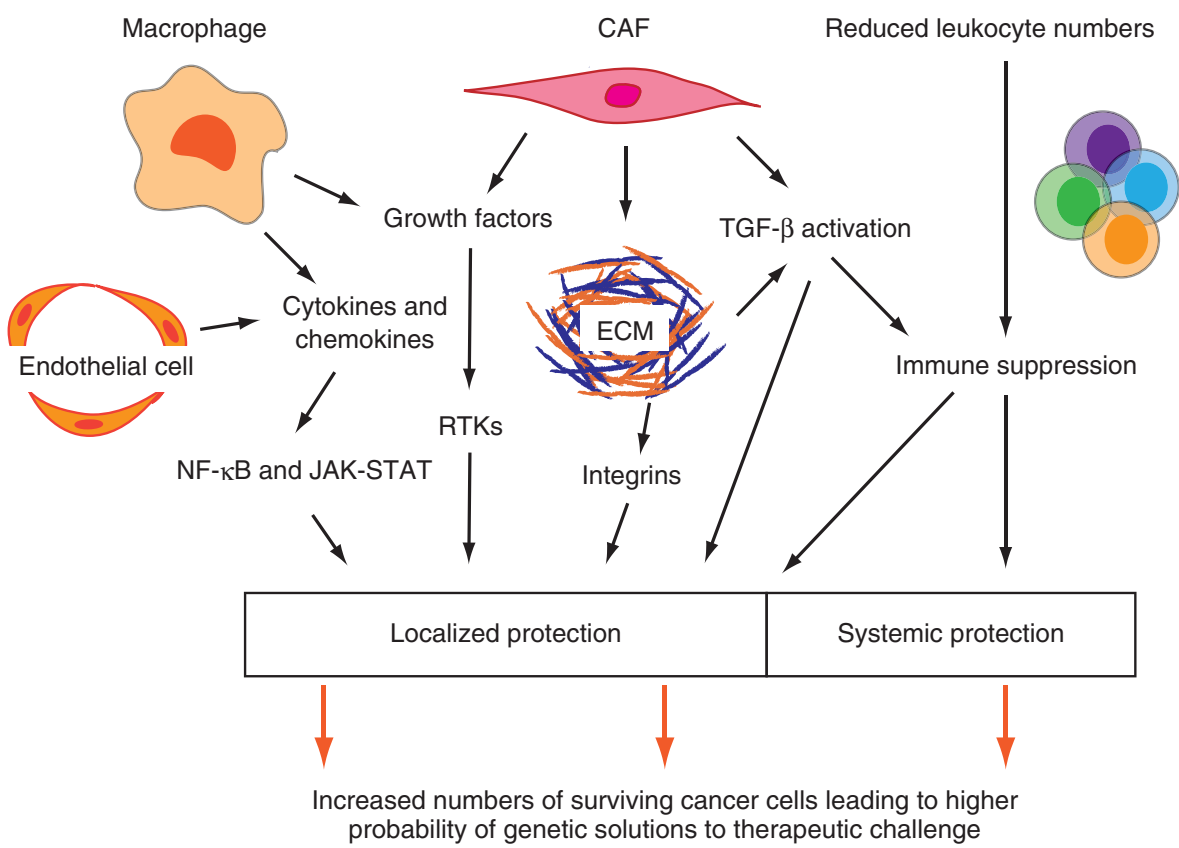

Figure 2. Major mechanisms by which the tumor microenvironment modulates the response to therapy. Stromal cells, including macrophages, endothelial cells, and fibroblasts, can produce growth factors, cytokines, and chemokines that locally promote cancer cell survival. Fibroblasts also play a major role in shaping the tumor extracellular matrix and this can promote prosurvival signals via integrins. The production and activation of transforming growth factor $\beta$ (TGF- $\beta$ ) by stromal cells can lead to immune suppression that further protects cancer cells; this can be both local and systemic. In addition, the reduction in leukocyte numbers caused by cytotoxic and radiotherapy can lead to further immune suppression.

tric/magnetic fields created in the tumor microenvironment strongly affect cancer cell mitosis, which is already used in the treatment of glioblastoma (Stupp et al. 2012; Swanson et al. 2016). Thus, the tumor microenvironment contains a complex mixture of biochemical and biophysical cues that modulate cell behavior and provide the environment in which the fittest cancer cells are selected in the absence of therapy. These same factors can also modulate the strong selective pressures applied by chemoand radiotherapy. Cancer treatments can also directly affect many of the cellular components of the microenvironment and further alter the context in which cancer evolution occurs.

\section{CANCER-STROMA INTERPLAY UNDER CYTOTOXIC REAGENTS}

The majority of cytotoxic chemotherapy agents either cause DNA damage, which is more diffi- cult for cells that are replicating their DNA to resolve, or perturb mitosis. Although these agents can cause levels of damage and structural defects that are incompatible with cell viability and lead to rapid cell death in vitro, the situation in vivo is more nuanced. Imaging studies have revealed that the kinetics of cell death are much slower in vivo and it is more likely that cytotoxic agents trigger cell death through interaction with various "checkpoints" and engagement of the apoptotic machinery (Janssen et al. 2013). These latter processes can be affected by external cues; indeed, several studies have indicated how the tumor microenvironment can modulate responses to cytotoxic drugs (Sherman-Baust et al. 2003; Gilbert and Hemann 2010; Nakasone et al. 2012; Sun et al. 2012; Dijkgraaf et al. 2013).

The cell death caused by chemotherapeutic agents can act as a trigger for the recruitment of myeloid cells (Ruffell and Coussens 2015). This 
is potentially because the dying cells generate similar signals to a wound. Indeed, the C-C motif chemokine ligand (CCL) $2 / \mathrm{C}-\mathrm{C}$ motif chemokine receptor (CCR) 2 and colony-stimulating factor (CSF) $1 / \mathrm{CSF} 1 \mathrm{R}$ axes play an important role in this process (DeNardo et al. 2011; Qian et al. 2011; Hughes et al. 2015). In the longer term, cytotoxic drugs may systemically reduce leukocyte numbers or skew the diversity of leukocytes produced, because they disrupt the expansion of hematopoietic stem cells. It is unclear what effect this has on the efficacy of cancer cell killing; however, it is associated with significant side effects, including neutropenia. To counteract this, granulocyte (G)-CSF is often given to patients to boost neutrophil numbers (Bennett et al. 2013). However, recent work has suggested that boosting neutrophil numbers in this way may actually lead to more aggressive tumor phenotypes (Antonio et al. 2015; Wculek and Malanchi 2015a,b).

The presence of tumor-associated macrophages can have several consequences for the tumor. This is partly attributable to the presence of different macrophages subtypes within tumors (Mantovani et al. 2005). In reductionist coculture experiments, macrophages can reduce the sensitivity of cancer cells to paclitaxel, etoposide, and doxorubicin (Shree et al. 2011). Signal transducer and activator of transcription (STAT) 3 and downstream transcription from inflammatory modulators are required in macrophages for the protection of pancreatic ductal adenocarcinoma cells (Mitchem et al. 2013). The production of cathepsin B by macrophages is important to protect breast tumors from the effect of paclitaxel (Bruchard et al. 2013). This may be caused by cathepsin B activating the inflammasome and thereby elevating the production of a range of cytokines. Interleukin (IL)- 6 is a possible mediator of this chemoprotection in both contexts. In addition to the production of growth factors and proteases, macrophages can affect cancer cell behavior through the production of exosomes, which are $\sim 150-\mathrm{nm}$ lipid-enclosed cell fragments. The exosomemediated transfer of miR-155 from monocytes to neuroblastoma cells reduces the cancer cells' sensitivity to cisplatin (Challagundla et al.
2015). Activated "M2-like" macrophages recruited to tumors following chemotherapy can also affect other aspects of the tumor phenotype. They express CXCL12/SDF1 $\alpha$, which is a promigratory cue for many cancer cells, and they produce vascular endothelial growth factor A (VEGF-A), which modulates the tumor vasculature and its leakiness ( $\mathrm{Du}$ et al. 2008). The combination of these events may contribute to increased dissemination of tumor cells following chemotherapy. Tumor-associated macrophages are also capable of immune suppression (Doedens et al. 2010; Ruffell et al. 2014). Together, these mechanisms tend to favor cancer cell survival following chemotherapy and support the idea that targeting macrophages may enhance the ability of conventional chemotherapy to eliminate tumors.

DNA damaging agents, such as doxorubicin, will also trigger DNA damage in stromal cells. Notably, triggering DNA damage in endothelial cells leads to increased NF- $\kappa \mathrm{B}$ activity and the elevated production of numerous cytokines, including the antiapoptotic cytokine IL6 , IL- $1 \alpha$, and granulocyte-macrophage (GM)CSF (Tavora et al. 2014). These factors then help to protect tumor cells from DNA damage. DNA damaging agents can drive certain stromal cell types, notably fibroblasts, into a state of irreversible cell-cycle arrest called senescence (Krtolica et al. 2001). Interestingly, this state is associated with a characteristic secretome, rich in chemokines and growth factors, such as CCL2, VEGF, and transforming growth factor (TGF) $\beta$, which is capable of reducing the effects of chemotherapy (Acosta et al. 2013). Mesenchymal stem cells can protect gastric cancer cells from cytotoxic therapies through producing exosomes that activate $\mathrm{Ca}^{2+}$ /calmodulin-dependent protein kinase and extracellular signal-regulated kinase (ERK)/ mitogen-activated protein kinase (MAPK) (Ji et al. 2015). The various mechanisms highlighted here are from a variety of model systems and may not act at once; nonetheless, it is clear that there are a multitude of mechanisms by which the efficacy of cytotoxic agents can be reduced by cells within the tumor microenvironment.

Stromal cells can also modulate the efficacy of therapy by influencing drug access to the 
tumor. The most well-studied example of this phenomenon is the tumor vasculature. The access of cytotoxic agents is typically reduced in poorly vascularized tumors, such as pancreatic ductal adenocarcinoma (Sofuni et al. 2005; Olive et al. 2009). However, the quality of the vasculature is also an important factor (Carmeliet and Jain 2011b). A high vessel density may not lead to efficient drug delivery if the vessels are poorly perfused. Further, high interstitial pressure within tumors can hamper drugs entering the tumor. In some systems, high internal pressure has been linked to stromal fibroblasts and the extracellular matrix. Interference with the activity of stromal fibroblasts can improve drug access and therapy response in preclinical models (Brown et al. 2003; Olive et al. 2009; Perentes et al. 2009).

\section{STROMAL MODULATION OF RESPONSES TO RADIOTHERAPY}

Radiotherapy is widely used to treat various types of cancers. Its primary mechanism of action is to cause DNA damage leading to cell death. Tumor targeting is largely achieved through physical methods of focusing the beam of radiation on the tumor. However, all cells within this region are likely to be affected. These effects of radiation on stromal cells have mainly been studied in the context of direct adverse reactions that might damage normal tissue/organ functions and worsen patients' quality of life. However, it is now becoming clear that the effect of radiation on stromal cells can affect therapeutic efficacy.

The most well-known microenvironmental factor to affect radiotherapy is oxygen tension (Semenza 2004). High oxygen levels enhance photon-based radiotherapy because oxygen can be converted to DNA-damaging free radicals by the radiation. As a result, a large effort has been devoted to improving tissue oxygenation concomitant with radiotherapy delivery (Barker et al. 2015). It has also been observed that vascular damage triggered by irradiation can contribute to its efficacy, possibly by reducing the availability of nutrients (Garcia-Barros et al. 2003). However, the situation is more complex as vascular repair processes can be initiated after radiotherapy and these can promote cancer cell survival. Irradiation induces tumor vasculogenesis through bone marrow-derived cell (BMDC) recruitment that supports tumor growth (Kioi et al. 2010; Kozin et al. 2010). Further, radiation induces hypoxia-inducible factor (HIF) 1-mediated expression of VEGF and basic fibroblast growth factor (bFGF) in cancer cells, which promotes endothelial cell survival and ultimately radioresistance (Moeller et al. 2004). This can be overcome by inhibiting HIF1 function after delivery radiotherapy. If HIF1 is inhibited before radiotherapy, then it hampers tumor killing by reducing cancer cell proliferation. These studies provide an example of how radiotherapy interacts with the stroma and the importance of considering the phasing of interventions when trying to overcome radioresistance.

In addition to direct killing of tumor cells, radiotherapy can promote antitumor immunity. The efficacy of radiotherapy relies on induction of type I interferon-dependent innate and adaptive immunity (Burnette et al. 2011). This is partly via activation of tumor-associated dendritic cells that in turn support tumor-specific effector $\mathrm{CD} 8^{+} \mathrm{T}$ cells (Gupta et al. 2012). The trigger for the activation of the immune system following irradiation is the activation of damage-associated molecular patterns and their corresponding pattern-recognition receptors (DAMP-PRR) (Apetoh et al. 2007). This class of receptors recognizes molecules associated with tissue damage; specifically, cell damage leads to the release of high mobility group box (HMGB) 1 and this subsequently triggers tolllike receptor (TLR) 4 signaling in dendritic cells (Scaffidi et al. 2002). It is likely that interactions with the immune system following radiotherapy are responsible for the abscopal effect, which is when disseminated tumors that were not directly targeted by radiotherapy also respond (Kaminski et al. 2005; Postow et al. 2012; Siva et al. 2015).

Fibroblasts are highly responsive to radiation, and linked to this is the phenomenon of radiation fibrosis (Yarnold and Brotons 2010). Radiation can activate fibroblasts in many ways. Vascular damage can lead to the leakage of se- 
rum components, such as lysophosphatidic acid (LPA), and proteases into tissue. LPA stimulates fibroblast contractility and extracellular matrix remodeling (Calvo et al. 2013). Proteases, including thrombin and plasmin, can activate TGF- $\beta$, which also promote the activation of fibroblasts (Barcellos-Hoff 1998). Once activated, fibroblasts can synthesize large amounts of collagens and organize them into dense fibrillary tissue. This abundance of matrix can promote cancer cell survival via integrin signaling. Blockade of integrin $\beta 1$ enhanced the efficacy radiotherapy in a model of small-cell lung carcinoma (Park et al. 2008; Mantoni et al. 2011). Fibroblasts can also promote radioresistance via a combination of Notch signaling and the transfer of exosomes that activate STAT1 to breast cancer cells (Boelens et al. 2014). Similar to cytotoxic drugs, radiation-induced DNA damage can drive fibroblasts into senescence and promote a secretome that includes high levels of TGF- $\beta$ ligands, VEGF-A, and various cytokines (Freund et al.2010; Acosta et al. 2013). Crucially, media conditioned by senescent fibroblasts confers radioresistance (Tsai et al. 2009). Increased levels of TGF- $\beta$ are a common feature of the microenvironment following radiation, although it should be noted that fibroblasts may not be the only source of TGF- $\beta$. Increased TGF$\beta$ levels can affect the subsequent progression of residual disease, thereby undermining the long-term efficacy of the therapy (Tsai et al. 2009). Further, the immune-suppressive effects of TGF- $\beta$ can prevent an effective immune response being triggered against the cancer cell debris that results from the cells killed by radiotherapy. Blockade of TGF- $\beta$ signaling can enhance CD8-mediated killing of tumor cells following radiation (Vanpouille-Box et al. 2015).

\section{MICROENVIRONMENTAL PROTECTION FROM TARGETED THERAPIES}

The last 15 years have seen the emergence of therapies targeted against oncogene protein products. Most notably, kinase inhibitors of BRAF, epidermal growth factor receptor (EGFR) and its homologs, and Abl are now used to treat tumors with oncogenic perturbation of these genes (O'Brien et al. 2003; PiccartGebhart et al. 2005; Romond et al. 2005; Shepherd et al. 2005; Druker et al. 2006; Mok et al. 2009; Flaherty et al. 2010; Kantarjian et al. 2010; Maemondo et al. 2010; Chapman et al. 2011). Despite the intention to target only cells containing the oncogenic mutation, it is now clear that kinase inhibitors can modulate the tumor stroma, and their efficacy is influenced by the presence or absence of certain stromal cues. Systematic analysis of the sensitivity of BRAF mutant melanoma cells to BRAF inhibition when cocultured with different stromal cells revealed that stromal fibroblasts reduce the efficacy of targeted therapy. This may, in part, be owing to their production of hepatocyte growth factor (HGF) that activates ERK/MAP kinase, signaling independently of the BRAF oncogene (Straussman et al. 2012; Wilson et al. 2012). In parallel, BRAF inhibitors can promote matrix remodeling by melanoma-associated fibroblasts. The remodeled extracellular matrix then promotes integrin- and focal adhesion kinase (FAK)-mediated signaling that also leads to BRAF-independent ERK/MAP kinase activity (Hirata et al. 2015). BRAF targeted therapies can also lead to selection for cancer cells that have increased expression of receptor tyrosine kinases in both melanoma and colon carcinoma (Nazarian et al. 2010; Diaz et al. 2012; Prahallad et al. 2012). The elevated level of these receptors renders the cancer cells more responsive to the corresponding ligands and promotes BRAF-independent ERK/MAPK. Tumor necrosis factor $\alpha$ (TNF- $\alpha$ ) production by tumor-associated macrophages can also protect melanoma cells from BRAF therapies (Smith et al. 2014) and soluble factors in cerebrospinal fluid can reduce the efficacy of BRAF inhibitors. This may partially explain the poor response of brain metastases to vemurafenib (Seifert et al. 2016). Fibroblast-derived HGF has also been implicated in the resistance of EGFR mutant lung cancer to EGFR inhibitors (Wang et al. 2009). These observations illustrate the multitude of mechanisms by which blockade of oncogenic kinases can be bypassed by signals from the tumor microenvironment. 


\section{CONSEQUENCES OF THE MICROENVIRONMENT FOR TUMOR EVOLUTION IN RESPONSE TO THERAPY}

The various complex microenvironmental changes described above have the potential to influence the evolution of the tumor following therapy. However, it is not straightforward to predict the ultimate consequence in terms of tumor progression and patient outcome. One general theme is that many microenvironmental mechanisms that counteract the efficacy of therapy will result in a larger pool of surviving cancer cells. Initially, the large majority of these cells will not be intrinsically resistant to the therapy, but the longer they persist the more likely they are to acquire a change, either genetic or epigenetic, that confers some fitness advantage for resisting the therapy. Thus, the residual pool of cancer cells can be viewed as the "raw material" on which all subsequent cancer evolution will act. The larger this pool is, the higher the probability of a favorable change occurring that will lead to the ultimate failure of the therapy. In this way, the prosurvival cues from the microenvironment enable tumor evolution. Consistent with this, blocking FAK-dependent prosurvival cues emanating from the stroma in BRAF mutant melanoma leads to both a more dramatic reduction in the tumor volume immediately after the initiation of combination therapy and a large extension in the time to ultimate therapy failure (Hirata et al. 2015).

Although the majority of cells within a tumor may not initially harbor mutations that confer therapy resistance, it is probable that a fraction of cells will contain genetic changes that make them less sensitive to the therapy being applied. For example, a low frequency of mutations conferring EGFR inhibitor resistance has been observed in lung and colorectal cancers (Inukai et al. 2006; Maheswaran et al. 2008; Diaz et al. 2012). How the microenvironment interacts with such clones is currently unclear. However, it is possible that cells containing mutations linked to resistance may not be optimally fit before therapy; indeed, if they had a strong fitness advantage they would already be dominant. It is possible that the microenvironment may provide supportive signals as such cells evolve toward a high level of fitness (Zhao et al. 2016).

The microenvironment also influences tumor evolution by the changing milieu of growth factors and other conditions following therapy. The altered levels of cytokines produced by stromal cells following either chemo- or radiotherapy will tend to favor cancer cells expressing the corresponding receptors. Similarly, the hypoxic microenvironment that remains following radiotherapy or antiangiogenic therapy will favor cancer cells that activate HIF1 $\alpha$. This can be problematic because HIF1-regulated transcriptional programs are linked to increased invasion and epithelial to mesenchymal transition (Zhao et al. 2014; El-Naggar et al. 2015).

In addition to therapy directly triggering changes in the signaling and proliferation of stromal cells, it is possible that therapies may select for different types of stromal cells. This could lead to evolution of the tumor microenvironment. Little definitive evidence exists about the evolution of stromal cells. This is largely caused by their genetic normality and the associated low mutation rate. Nonetheless, several studies have reported some genetic alterations in cancer-associated fibroblasts (Polyak et al. 2009). Some of this work has been contentious because of the difficulty of obtaining pure stromal samples and excluding cancer cells that may have undergone a profound EMTor vascular mimicry (Seftor et al. 2012). New methods involving deep sequencing of stromal populations at various time points during tumor progression and therapy should help to clarify this matter.

\section{TARGETING THE TUMOR-STROMA INTERACTIONS TO IMPROVE THERAPEUTIC OUTCOMES}

Ultimately, the goal of cancer therapies is to eliminate the transformed cells, or at least convert them into a harmless nonproliferative state. In both cases, it is important to consider the selective pressures and possibilities for cancer evolution. In the former case, the therapy either needs to be so detrimental to the cancer cells 
that the probability of the appropriate permutation of genetic or epigenetic changes occurring that would lead to resistance is so low that it is highly improbable. The likelihood of a particular set of changes occurring depends on several factors, including the number of cells, their proliferation rate, and their genomic stability. As detailed above, microenvironmental factors can undermine the efficacy of chemo- and radiotherapy, thereby leading to increased cancer cell numbers following treatment. This raises the possibility that by targeting the tumor microenvironment, or signals coming from it, the ultimate rate of therapy failure can be reduced. Currently, considerable effort is being given to identify the most effective microenvironmental targets and the existing therapies with which they should be combined (Junttila and de Sauvage 2013). One approach is to perturb either the recruitment or function of stromal cells. The combination of targeting macrophages alongside conventional therapies is yielding encouraging results. The CSF1/CSF1R axis is critical for several aspects of macrophage biology. Blockade of this axis has shown promising results in several preclinical models (Mitchem et al. 2013; Pyonteck et al. 2013); notably, it can enhance the efficacy of conventional cytotoxic therapies (Paulus et al. 2006; Ruffell et al. 2014). Genetic perturbation of CCL2/CCR2 signaling, which also affects myeloid cell recruitment, improves the efficacy of doxorubicin delivery and therapeutic responses (Nakasone et al. 2012). The targeting of CAFs has also been explored using blockade of Hedgehog signaling; however, despite encouraging preclinical data the clinical results are disappointing (Amakye et al. 2013). This is likely attributable to CAFs having both pro- and antitumorigenic functions (Ozdemir et al. 2014). Most recently, immunotherapy approaches that involve blocking the immune-suppressive cytotoxic T-lymphocyte-associated protein (CTLA) 4 or PD1 signaling have yielded promising results. These improve T-cell mediated elimination of cancer cells and can lead to durable responses. (For a more thorough review of this expanding field, readers are directed to recent articles by Pardoll [2012] and Topalian et al. [2015].)
A major focus of therapies targeting the microenvironment is the modulation of tumor vasculature. Agents targeting the proangiogenic receptor tyrosine kinase VEGFR2 are now used for the treatment of several cancer types; however, their efficacy is not as great as was initially hoped. The reasons for this are complex and extensively reviewed elsewhere (Carmeliet and Jain 2011a); but it is emerging that there are some interesting consequences for tumor evolution. The hypoxic environment that is triggered by reducing the tumor vasculature favors tumor cells with activation of $\mathrm{HIF} 1 \alpha$, and this is linked to greater tumor invasion. In preclinical models, this leads to increased metastasis following VEGFR2 inhibition (Paez-Ribes et al. 2009; Keunen et al. 2011). Conversely, boosting VEGFR2 signaling can improve therapeutic responses (Wong et al. 2015). These studies highlight the complex and sometimes counterintuitive effect of targeting the tumor microenvironment. They have also given rise to the idea that optimal therapeutic benefit may be achieved by returning the vasculature, or other components of the tumor microenvironment, to a normal state. Modest perturbation of hypoxia-responsive signaling (prolyl hydroxylase domain-containing protein (PHD) 2 heterozygosity) leads to more normal blood vessels and improved therapeutic responses (Mazzone et al. 2009). Vascular promotion may also be an effective way of delivery more drugs to tumors and avoid the selection of aggressive cancer cell phenotypes in hypoxic environments (Wong et al. 2015).

Targeting the prosurvival signals emanating from the microenvironment is another obvious way to improve the efficacy of conventional therapies. Blocking integrin signaling or downstream tyrosine kinase signaling resulting from cancer cell engagement with the extracellular matrix can improve the efficacy of radiotherapy and oncogene targeted therapy (Park et al. 2006, 2008; Hirata et al. 2015). The potential for long-term disease modulation via the microenvironment has also been shown in experiments grafting malignant cells into developing tissues. Aggressive human breast cancer cells will adopt "normal" developmental fates if 
grafted into the developing murine mammary gland (Bussard et al. 2010; Bussard and Smith 2012). Similarly, melanoma cells will follow a neural crest fate when transplanted into chick eggs (Kulesa et al. 2006) and the chick egg environment can suppress Src-driven transformation (Dolberg and Bissell 1984). The molecular pathways underpinning these observations remain opaque; however, signals from the extracellular matrix are likely to play a role as basement membrane components can greatly reduce the malignant phenotype of human breast cancer (Nguyen-Ngoc et al. 2012). Once the signaling underpinning these findings is better understood, then the possibility of therapeutically triggering them will be an appealing possibility.

In addition to mutation and proliferation rates, the rate of tumor evolution also depends on the strength of selective pressure applied and the relative fitness differences that may occur between cancer cells. This could also be exploited for therapeutic benefit, but requires an almost opposite approach. Instead of maximizing the elimination of tumor cells, the goal becomes to minimize competitive advantages between cancer cells while preventing the tumor from reaching a size that is clinically problematic. The potential applicability of this approach is illustrated by a study that modulated the level of chemotherapy such that tumors did not reduce their size, but that tumor size was simply maintained (Gatenby et al. 2009). Interestingly, this led to better disease control (Gatenby et al. 2009). It is possible that the suppression of malignancy by developmental microenvironments described above is the result of a reduced fitness differential between the transformed and normal cells.

\section{CONCLUDING REMARKS}

The examples above illustrate the different ways in which an improved understanding of the cancer microenvironment is informing ongoing efforts to improve cancer treatment. First, the elimination of the various prosurvival cues from the environment that undermine therapy will improve initial responses and limit the possibilities for cancer cells evolving to become therapy resistant. Second, by modulating the environment and therefore the fitness differential between cancer cells, the rate and direction of tumor evolution might be controlled. The coming years should see advances in both areas and hopefully improve therapeutic outcomes.

\section{REFERENCES}

Acosta JC, Banito A, Wuestefeld T, Georgilis A, Janich P, Morton JP, Athineos D, Kang TW, Lasitschka F, Andrulis $\mathrm{M}$, et al. 2013. A complex secretory program orchestrated by the inflammasome controls paracrine senescence. Nat Cell Biol 15: 978-990.

Amakye D, Jagani Z, Dorsch M. 2013. Unraveling the therapeutic potential of the Hedgehog pathway in cancer. Nat Med 19: 1410-1422.

Antonio N, Bonnelykke-Behrndtz ML, Ward LC, Collin J, Christensen IJ, Steiniche T, Schmidt H, Feng Y, Martin P. 2015. The wound inflammatory response exacerbates growth of pre-neoplastic cells and progression to cancer. EMBO J 34: 2219-2236.

Apetoh L, Ghiringhelli F, Tesniere A, Obeid M, Ortiz C, Criollo A, Mignot G, Maiuri MC, Ullrich E, Saulnier P, et al. 2007. Toll-like receptor 4-dependent contribution of the immune system to anticancer chemotherapy and radiotherapy. Nat Med 13: 1050-1059.

Barcellos-Hoff MH. 1998. How do tissues respond to damage at the cellular level? The role of cytokines in irradiated tissues. Radiat Res 150: S109-S120.

Barker HE, Paget JT, Khan AA, Harrington KJ. 2015. The tumour microenvironment after radiotherapy: Mechanisms of resistance and recurrence. Nat Rev Cancer 15: 409-425.

Bennett CL, Djulbegovic B, Norris LB, Armitage JO. 2013. Colony-stimulating factors for febrile neutropenia during cancer therapy. $N$ Engl J Med 368: 1131-1139.

Bhowmick NA, Neilson EG, Moses HL. 2004. Stromal fibroblasts in cancer initiation and progression. Nature 432: 332-337.

Boelens MC, Wu TJ, Nabet BY, Xu B, Qiu Y, Yoon T, Azzam DJ, Twyman-Saint Victor C, Wiemann BZ, Ishwaran $\mathrm{H}$, et al. 2014. Exosome transfer from stromal to breast cancer cells regulates therapy resistance pathways. Cell 159: 499-513.

Brown E, McKee T, diTomaso E, Pluen A, Seed B, Boucher Y, Jain RK. 2003. Dynamic imaging of collagen and its modulation in tumors in vivo using second-harmonic generation. Nat Med 9: 796-800.

Bruchard M, Mignot G, Derangere V, Chalmin F, Chevriaux A, Vegran F, Boireau W, Simon B, Ryffel B, Connat JL, et al. 2013. Chemotherapy-triggered cathepsin B release in myeloid-derived suppressor cells activates the Nlrp3 inflammasome and promotes tumor growth. Nat Med 19: 57-64.

Burnette BC, Liang H, Lee Y, Chlewicki L, Khodarev NN, Weichselbaum RR, Fu YX, Auh SL. 2011. The efficacy of 
radiotherapy relies upon induction of type I interferondependent innate and adaptive immunity. Cancer Res 71: 2488-2496.

Bussard KM, Smith GH. 2012. Human breast cancer cells are redirected to mammary epithelial cells upon interaction with the regenerating mammary gland microenvironment in-vivo. PLoS ONE 7: e49221.

Bussard KM, Boulanger CA, Booth BW, Bruno RD, Smith GH. 2010. Reprogramming human cancer cells in the mouse mammary gland. Cancer Res 70: 6336-6343.

Butcher DT, Alliston T, Weaver VM. 2009. A tense situation: Forcing tumour progression. Nat Rev Cancer 9: 108-122.

Calvo F, Ege N, Grande-Garcia A, Hooper S, Jenkins RP, Chaudhry SI, Harrington K, Williamson P, Moeendarbary E, Charras G, et al. 2013. Mechanotransduction and YAP-dependent matrix remodelling is required for the generation and maintenance of cancer-associated fibroblasts. Nat Cell Biol 15: 637-646.

Carmeliet P, Jain RK. 2000. Angiogenesis in cancer and other diseases. Nature 407: 249-257.

Carmeliet P, Jain RK. 2011a. Molecular mechanisms and clinical applications of angiogenesis. Nature 473: 298 307.

Carmeliet P, Jain RK. 2011b. Principles and mechanisms of vessel normalization for cancer and other angiogenic diseases. Nat Rev Drug Discov 10: 417-427.

Challagundla KB, Wise PM, Neviani P, Chava H, Murtadha M, Xu T, Kennedy R, Ivan C, Zhang X, Vannini I, et al. 2015. Exosome-mediated transfer of microRNAs within the tumor microenvironment and neuroblastoma resistance to chemotherapy. J Natl Cancer Inst 107: djv135.

Chapman PB, Hauschild A, Robert C, Haanen JB, Ascierto P, Larkin J, Dummer R, Garbe C, Testori A, Maio M, et al. 2011. Improved survival with vemurafenib in melanoma with BRAF V600E mutation. N Engl J Med 364: $2507-$ 2516.

Damaghi M, Tafreshi NK, Lloyd MC, Sprung R, Estrella V, Wojtkowiak JW, Morse DL, Koomen JM, Bui MM, Gatenby RA, et al. 2015. Chronic acidosis in the tumour microenvironment selects for overexpression of LAMP2 in the plasma membrane. Nat Commun 6: 8752 .

DeNardo DG, Brennan DJ, Rexhepaj E, Ruffell B, Shiao SL, Madden SF, Gallagher WM, Wadhwani N, Keil SD, Junaid SA, et al. 2011. Leukocyte complexity predicts breast cancer survival and functionally regulates response to chemotherapy. Cancer Discov 1: 54-67.

Diaz LA Jr, Williams RT, Wu J, Kinde I, Hecht JR, Berlin J, Allen B, Bozic I, Reiter JG, Nowak MA, et al. 2012. The molecular evolution of acquired resistance to targeted EGFR blockade in colorectal cancers. Nature 486: 537540.

Dijkgraaf EM, Heusinkveld M, Tummers B, Vogelpoel LT, Goedemans R, Jha V, Nortier JW, Welters MJ, Kroep JR, van der Burg SH. 2013. Chemotherapy alters monocyte differentiation to favor generation of cancer-supporting M2 macrophages in the tumor microenvironment. Cancer Res 73: 2480-2492.

Doedens AL, Stockmann C, Rubinstein MP, Liao D, Zhang N, DeNardo DG, Coussens LM, Karin M, Goldrath AW, Johnson RS. 2010. Macrophage expression of hypoxiainducible factor- $1 \alpha$ suppresses T-cell function and promotes tumor progression. Cancer Res 70: 7465-7475.
Dolberg DS, Bissell MJ. 1984. Inability of Rous sarcoma virus to cause sarcomas in the avian embryo. Nature 309: $552-556$.

Druker BJ, Guilhot F, O’Brien SG, Gathmann I, Kantarjian H, Gattermann N, Deininger MW, Silver RT, Goldman JM, Stone RM, et al. 2006. Five-year follow-up of patients receiving imatinib for chronic myeloid leukemia. $N$ Engl J Med 355: 2408-2417.

Du R, Lu KV, Petritsch C, Liu P, Ganss R, Passegue E, Song H, Vandenberg S, Johnson RS, Werb Z, et al. 2008. HIF1 $\alpha$ induces the recruitment of bone marrow-derived vascular modulatory cells to regulate tumor angiogenesis and invasion. Cancer Cell 13: 206-220.

Eales KL, Hollinshead KE, Tennant DA. 2016. Hypoxia and metabolic adaptation of cancer cells. Oncogenesis 5: e190.

El-Naggar AM, Veinotte CJ, Cheng H, Grunewald TG, Negri GL, Somasekharan SP, Corkery DP, Tirode F, Mathers J, Khan D, et al. 2015. Translational activation of HIF $1 \alpha$ by YB-1 promotes sarcoma metastasis. Cancer Cell 27: 682697.

Flaherty KT, Puzanov I, Kim KB, Ribas A, McArthur GA, Sosman JA, O’Dwyer PJ, Lee RJ, Grippo JF, Nolop K, et al. 2010. Inhibition of mutated, activated BRAF in metastatic melanoma. N Engl J Med 363: 809-819.

Freund A, Orjalo AV, Desprez PY, Campisi J. 2010. Inflammatory networks during cellular senescence: Causes and consequences. Trends Mol Med 16: 238-246.

Garcia-Barros M, Paris F, Cordon-Cardo C, Lyden D, Rafii S, Haimovitz-Friedman A, Fuks Z, Kolesnick R. 2003. Tumor response to radiotherapy regulated by endothelial cell apoptosis. Science 300: 1155-1159.

Gatenby RA, Gillies RJ. 2004. Why do cancers have high aerobic glycolysis? Nat Rev Cancer 4: 891-899.

Gatenby RA, Silva AS, Gillies RJ, Frieden BR. 2009. Adaptive therapy. Cancer Res 69: 4894-4903.

Gilbert LA, Hemann MT. 2010. DNA damage-mediated induction of a chemoresistant niche. Cell 143: 355-366.

Grivennikov SI, Greten FR, Karin M. 2010. Immunity, inflammation, and cancer. Cell 140: 883-899.

Gupta A, Probst HC, Vuong V, Landshammer A, Muth S, Yagita H, Schwendener R, Pruschy M, Knuth A, van den Broek M. 2012. Radiotherapy promotes tumor-specific effector $\mathrm{CD}^{+} \mathrm{T}$ cells via dendritic cell activation. J Immunol 189: 558-566.

Hanahan D, Coussens LM. 2012. Accessories to the crime: Functions of cells recruited to the tumor microenvironment. Cancer Cell 21: 309-322.

Hanahan D, Weinberg RA. 2011. Hallmarks of cancer: The next generation. Cell 144: 646-674.

Harney AS, Arwert EN, Entenberg D, Wang Y, Guo P, Qian BZ, Oktay MH, Pollard JW, Jones JG, Condeelis JS. 2015. Real-time imaging reveals local, transient vascular permeability, and tumor cell intravasation stimulated by TIE2 ${ }^{\text {hi }}$ macrophage-derived VEGFA. Cancer Discov 5: 932-943.

Hirata E, Girotti MR, Viros A, Hooper S, Spencer-Dene B, Matsuda M, Larkin J, Marais R, Sahai E. 2015. Intravital imaging reveals how BRAF inhibition generates drugtolerant microenvironments with high integrin $\beta 1 /$ FAK signaling. Cancer Cell 27: 574-588. 
Hughes R, Qian BZ, Rowan C, Muthana M, Keklikoglou I, Olson OC, Tazzyman S, Danson S, Addison C, Clemons M, et al. 2015. Perivascular M2 macrophages stimulate tumor relapse after chemotherapy. Cancer Res 75: 3479_ 3491

Inukai $\mathrm{M}$, Toyooka $\mathrm{S}$, Ito $\mathrm{S}$, Asano $\mathrm{H}$, Ichihara $\mathrm{S}$, Soh J, Suehisa H, Ouchida M, Aoe K, Aoe M, et al. 2006. Presence of epidermal growth factor receptor gene T790M mutation as a minor clone in non-small cell lung cancer. Cancer Res 66: 7854-7858.

Iwai Y, Ishida M, Tanaka Y, Okazaki T, Honjo T, Minato N. 2002. Involvement of PD-L1 on tumor cells in the escape from host immune system and tumor immunotherapy by PD-L1 blockade. Proc Natl Acad Sci 99: 12293-12297.

Janssen A, Beerling E, Medema R, van Rheenen J. 2013. Intravital FRET imaging of tumor cell viability and mitosis during chemotherapy. PLoS ONE 8: e64029.

Ji R, Zhang B, Zhang X, Xue J, Yuan X, Yan Y, Wang M, Zhu W, Qian H, Xu W. 2015. Exosomes derived from human mesenchymal stem cells confer drug resistance in gastric cancer. Cell Cycle 14: 2473-2483.

Joyce JA, Pollard JW. 2009. Microenvironmental regulation of metastasis. Nat Rev Cancer 9: 239-252.

Junttila MR, de Sauvage FJ. 2013. Influence of tumour micro-environment heterogeneity on therapeutic response. Nature 501: 346-354.

Kalluri R, Zeisberg M. 2006. Fibroblasts in cancer. Nat Rev Cancer 6: 392-401.

Kaminski JM, Shinohara E, Summers JB, Niermann KJ, Morimoto A, Brousal J. 2005. The controversial abscopal effect. Cancer Treat Rev 31: 159-172.

Kantarjian H, Shah NP, Hochhaus A, Cortes J, Shah S, Ayala M, Moiraghi B, Shen Z, Mayer J, Pasquini R, et al. 2010. Dasatinib versus imatinib in newly diagnosed chronicphase chronic myeloid leukemia. $N$ Engl J Med 362: 2260-2270.

Keunen O, Johansson M, Oudin A, Sanzey M, Rahim SA, Fack F, Thorsen F, Taxt T, Bartos M, Jirik R, et al. 2011. Anti-VEGF treatment reduces blood supply and increases tumor cell invasion in glioblastoma. Proc Natl Acad Sci 108: $3749-3754$

Kioi M, Vogel H, Schultz G, Hoffman RM, Harsh GR, Brown JM. 2010. Inhibition of vasculogenesis, but not angiogenesis, prevents the recurrence of glioblastoma after irradiation in mice. J Clin Invest 120: 694-705.

Kozin SV, Kamoun WS, Huang Y, Dawson MR, Jain RK, Duda DG. 2010. Recruitment of myeloid but not endothelial precursor cells facilitates tumor regrowth after local irradiation. Cancer Res 70: 5679-5685.

Krtolica A, Parrinello S, Lockett S, Desprez PY, Campisi J. 2001. Senescent fibroblasts promote epithelial cell growth and tumorigenesis: A link between cancer and aging. Proc Natl Acad Sci 98: 12072-12077.

Kulesa PM, Kasemeier-Kulesa JC, Teddy JM, Margaryan NV, Seftor EA, Seftor RE, Hendrix MJ. 2006. Reprogramming metastatic melanoma cells to assume a neural crest celllike phenotype in an embryonic microenvironment. Proc Natl Acad Sci 103: 3752-3757.

Levental KR, Yu H, Kass L, Lakins JN, Egeblad M, Erler JT, Fong SF, Csiszar K, Giaccia A, Weninger W, et al. 2009.
Matrix crosslinking forces tumor progression by enhancing integrin signaling. Cell 139: 891-906.

Madar S, Goldstein I, Rotter V. 2013. "Cancer associated fibroblasts"-More than meets the eye. Trends Mol Med 19: 447-453.

Maemondo M, Inoue A, Kobayashi K, Sugawara S, Oizumi S, Isobe H, Gemma A, Harada M, Yoshizawa H, Kinoshita I, et al. 2010. Gefitinib or chemotherapy for non-smallcell lung cancer with mutated EGFR. $N$ Engl J Med 362: 2380-2388.

Maheswaran S, Sequist LV, Nagrath S, Ulkus L, Brannigan B, Collura CV, Inserra E, Diederichs S, Iafrate AJ, Bell DW, et al. 2008. Detection of mutations in EGFR in circulating lung-cancer cells. N Engl J Med 359: 366-377.

Mantoni TS, Lunardi S, Al-Assar O, Masamune A, Brunner TB. 2011. Pancreatic stellate cells radioprotect pancreatic cancer cells through $\beta 1$-integrin signaling. Cancer Res 71: 3453-3458.

Mantovani A, Sica A, Locati M. 2005. Macrophage polarization comes of age. Immunity 23: 344-346.

Mazzone M, Dettori D, Leite de Oliveira R, Loges S, Schmidt T, Jonckx B, Tian YM, Lanahan AA, Pollard P, Ruiz de Almodovar C, et al. 2009. Heterozygous deficiency of PHD2 restores tumor oxygenation and inhibits metastasis via endothelial normalization. Cell 136: 839-851.

McAllister SS, Weinberg RA. 2014. The tumour-induced systemic environment as a critical regulator of cancer progression and metastasis. Nat Cell Biol 16: 717-727.

Melero I, Berman DM, Aznar MA, Korman AJ, Perez Gracia JL, Haanen J. 2015. Evolving synergistic combinations of targeted immunotherapies to combat cancer. Nat Rev Cancer 15: 457-472.

Miller JF, Sadelain M. 2015. The journey from discoveries in fundamental immunology to cancer immunotherapy. Cancer Cell 27: 439-449.

Mitchem JB, Brennan DJ, Knolhoff BL, Belt BA, Zhu Y, Sanford DE, Belaygorod L, Carpenter D, Collins L, Piwnica-Worms D, et al. 2013. Targeting tumor-infiltrating macrophages decreases tumor-initiating cells, relieves immunosuppression, and improves chemotherapeutic responses. Cancer Res 73: 1128-1141.

Mittal D, Gubin MM, Schreiber RD, Smyth MJ. 2014. New insights into cancer immunoediting and its three component phases-Elimination, equilibrium and escape. Curr Opin Immunol 27: 16-25.

Moeller BJ, Cao Y, Li CY, Dewhirst MW. 2004. Radiation activates HIF-1 to regulate vascular radiosensitivity in tumors: Role of reoxygenation, free radicals, and stress granules. Cancer Cell 5: 429-441.

Mok TS, Wu YL, Thongprasert S, Yang CH, Chu DT, Saijo N, Sunpaweravong P, Han B, Margono B, Ichinose Y, et al. 2009. Gefitinib or carboplatin-paclitaxel in pulmonary adenocarcinoma. N Engl J Med 361: 947-957.

Nakasone ES, Askautrud HA, Kees T, Park JH, Plaks V, Ewald AJ, Fein M, Rasch MG, Tan YX, Qiu J, et al. 2012. Imaging tumor-stroma interactions during chemotherapy reveals contributions of the microenvironment to resistance. Cancer Cell 21: 488-503.

Nazarian R, Shi H, Wang Q, Kong X, Koya RC, Lee H, Chen Z, Lee MK, Attar N, Sazegar H, et al. 2010. Melanomas 
acquire resistance to B-RAF(V600E) inhibition by RTK or N-RAS upregulation. Nature 468: 973-977.

Nguyen-Ngoc KV, Cheung KJ, Brenot A, Shamir ER, Gray RS, Hines WC, Yaswen P, Werb Z, Ewald AJ. 2012. ECM microenvironment regulates collective migration and local dissemination in normal and malignant mammary epithelium. Proc Natl Acad Sci 109: E2595-2604.

O’Brien SG, Guilhot F, Larson RA, Gathmann I, Baccarani M, Cervantes F, Cornelissen JJ, Fischer T, Hochhaus A, Hughes T, et al. 2003. Imatinib compared with interferon and low-dose cytarabine for newly diagnosed chronicphase chronic myeloid leukemia. $N$ Engl J Med 348: 994-1004.

Olive KP, Jacobetz MA, Davidson CJ, Gopinathan A, McIntyre D, Honess D, Madhu B, Goldgraben MA, Caldwell ME, Allard D, et al. 2009. Inhibition of Hedgehog signaling enhances delivery of chemotherapy in a mouse model of pancreatic cancer. Science 324: 1457-1461.

Orimo A, Gupta PB, Sgroi DC, Arenzana-Seisdedos F, Delaunay T, Naeem R, Carey VJ, Richardson AL, Weinberg RA. 2005. Stromal fibroblasts present in invasive human breast carcinomas promote tumor growth and angiogenesis through elevated SDF-1/CXCL12 secretion. Cell 121: 335-348.

Ozdemir BC, Pentcheva-Hoang T, Carstens JL, Zheng X, Wu CC, Simpson TR, Laklai H, Sugimoto H, Kahlert C, Novitskiy SV, et al. 2014. Depletion of carcinoma-associated fibroblasts and fibrosis induces immunosuppression and accelerates pancreas cancer with reduced survival. Cancer Cell 25: 719-734.

Paez-Ribes M, Allen E, Hudock J, Takeda T, Okuyama H, Vinals F, Inoue M, Bergers G, Hanahan D, Casanovas O. 2009. Antiangiogenic therapy elicits malignant progression of tumors to increased local invasion and distant metastasis. Cancer Cell 15: 220-231.

Pardoll DM. 2012. The blockade of immune checkpoints in cancer immunotherapy. Nat Rev Cancer 12: 252-264.

Park CC, Zhang H, Pallavicini M, Gray JW, Baehner F, Park CJ, Bissell MJ. 2006. $\beta_{1}$ integrin inhibitory antibody induces apoptosis of breast cancer cells, inhibits growth, and distinguishes malignant from normal phenotype in three dimensional cultures and in vivo. Cancer Res 66: $1526-1535$.

Park CC, Zhang HJ, Yao ES, Park CJ, Bissell MJ. 2008. $\beta_{1}$ integrin inhibition dramatically enhances radiotherapy efficacy in human breast cancer xenografts. Cancer Res 68: 4398-4405.

Paszek MJ, Zahir N, Johnson KR, Lakins JN, Rozenberg GI, Gefen A, Reinhart-King CA, Margulies SS, Dembo M, Boettiger D, et al. 2005. Tensional homeostasis and the malignant phenotype. Cancer Cell 8: 241-254.

Paulus P, Stanley ER, Schafer R, Abraham D, Aharinejad S. 2006. Colony-stimulating factor- 1 antibody reverses chemoresistance in human MCF-7 breast cancer xenografts. Cancer Res 66: 4349-4356.

Perentes JY, McKee TD, Ley CD, Mathiew H, Dawson M, Padera TP, Munn LL, Jain RK, Boucher Y. 2009. In vivo imaging of extracellular matrix remodeling by tumorassociated fibroblasts. Nat Method 6: 143-145.

Piccart-Gebhart MJ, Procter M, Leyland-Jones B, Goldhirsch A, Untch M, Smith I, Gianni L, Baselga J, Bell R, Jackisch C, et al. 2005. Trastuzumab after adjuvant che- motherapy in HER2-positive breast cancer. N Engl J Med 353: $1659-1672$.

Polyak K, Haviv I, Campbell IG. 2009. Co-evolution of tumor cells and their microenvironment. Trends Genet 25: 30-38.

Postow MA, Callahan MK, Barker CA, Yamada Y, Yuan J, Kitano S, Mu Z, Rasalan T, Adamow M, Ritter E, et al. 2012. Immunologic correlates of the abscopal effect in a patient with melanoma. N Engl J Med 366: 925-931.

Prahallad A, Sun C, Huang S, Di Nicolantonio F, Salazar R, Zecchin D, Beijersbergen RL, Bardelli A, Bernards R. 2012. Unresponsiveness of colon cancer to BRAF (V600E) inhibition through feedback activation of EGFR. Nature 483: 100-103.

Pyonteck SM, Akkari L, Schuhmacher AJ, Bowman RL, Sevenich L, Quail DF, Olson OC, Quick ML, Huse JT, Teijeiro V, et al. 2013. CSF-1R inhibition alters macrophage polarization and blocks glioma progression. Nat Med 19: 1264-1272.

Qian BZ, Li J, Zhang H, Kitamura T, Zhang J, Campion LR, Kaiser EA, Snyder LA, Pollard JW. 2011. CCL2 recruits inflammatory monocytes to facilitate breast-tumour metastasis. Nature 475: 222-225.

Qian BZ, Pollard JW. 2010. Macrophage diversity enhances tumor progression and metastasis. Cell 141: 39-51.

Reymond N, d'Agua BB, Ridley AJ. 2013. Crossing the endothelial barrier during metastasis. Nat Rev Cancer 13: 858-870.

Rhim AD, Oberstein PE, Thomas DH, Mirek ET, Palermo CF, Sastra SA, Dekleva EN, Saunders T, Becerra CP, Tattersall IW, et al. 2014. Stromal elements act to restrain, rather than support, pancreatic ductal adenocarcinoma. Cancer Cell 25: 735-747.

Romond EH, Perez EA, Bryant J, Suman VJ, Geyer CE Jr, Davidson NE, Tan-Chiu E, Martino S, Paik S, Kaufman PA, et al. 2005. Trastuzumab plus adjuvant chemotherapy for operable HER2-positive breast cancer. N Engl J Med 353: $1673-1684$.

Ruffell B, Coussens LM. 2015. Macrophages and therapeutic resistance in cancer. Cancer Cell 27: 462-472.

Ruffell B, Chang-Strachan D, Chan V, Rosenbusch A, Ho CM, Pryer N, Daniel D, Hwang ES, Rugo HS, Coussens LM. 2014. Macrophage IL-10 blocks CD ${ }^{+}$T cell-dependent responses to chemotherapy by suppressing IL-12 expression in intratumoral dendritic cells. Cancer Cell 26: 623-637.

Scaffidi P, Misteli T, Bianchi ME. 2002. Release of chromatin protein HMGB1 by necrotic cells triggers inflammation. Nature 418: 191-195.

Seftor RE, Hess AR, Seftor EA, Kirschmann DA, Hardy KM, Margaryan NV, Hendrix MJ. 2012. Tumor cell vasculogenic mimicry: From controversy to therapeutic promise. Am J Pathol 181: 1115-1125.

Seifert H, Hirata E, Gore M, Khabra K, Messiou C, Larkin J, Sahai E. 2016. Extrinsic factors can mediate resistance to BRAF inhibition in central nervous system melanoma metastases. Pigment Cell Melanoma Res 29: 92-100.

Semenza GL. 2004. Intratumoral hypoxia, radiation resistance, and HIF-1. Cancer Cell 5: 405-406.

Shepherd FA, Rodrigues Pereira J, Ciuleanu T, Tan EH, Hirsh V, Thongprasert S, Campos D, Maoleekoonpiroj S, Smy- 
E. Hirata and E. Sahai

lie M, Martins R, et al. 2005. Erlotinib in previously treated non-small-cell lung cancer. $N$ Engl J Med 353: 123 132.

Sherman-Baust CA, Weeraratna AT, Rangel LB, Pizer ES Cho KR, Schwartz DR, Shock T, Morin PJ. 2003. Remodeling of the extracellular matrix through overexpression of collagen VI contributes to cisplatin resistance in ovarian cancer cells. Cancer Cell 3: 377-386.

Shree T, Olson OC, Elie BT, Kester JC, Garfall AL, Simpson K, Bell-McGuinn KM, Zabor EC, Brogi E, Joyce JA. 2011. Macrophages and cathepsin proteases blunt chemotherapeutic response in breast cancer. Genes Dev 25: $2465-$ 2479.

Siva S, MacManus MP, Martin RF, Martin OA. 2015. Abscopal effects of radiation therapy: A clinical review for the radiobiologist. Cancer Lett 356: 82-90.

Smith MP, Sanchez-Laorden B, O'Brien K, Brunton H, Ferguson J, Young H, Dhomen N, Flaherty KT, Frederick DT, Cooper ZA, et al. 2014. The immune microenvironment confers resistance to MAPK pathway inhibitors through macrophage-derived TNFo. Cancer Discov 4: $1214-$ 1229.

Sofuni A, Iijima H, Moriyasu F, Nakayama D, Shimizu M, Nakamura K, Itokawa F, Itoi T. 2005. Differential diagnosis of pancreatic tumors using ultrasound contrast imaging. J Gastroenterol 40: 518-525.

Straussman R, Morikawa T, Shee K, Barzily-Rokni M, Qian ZR, Du J, Davis A, Mongare MM, Gould J, Frederick DT, et al. 2012. Tumour micro-environment elicits innate resistance to RAF inhibitors through HGF secretion. $\mathrm{Na}$ ture 487: 500-504.

Stupp R, Wong ET, Kanner AA, Steinberg D, Engelhard H, Heidecke V, Kirson ED, Taillibert S, Liebermann F, Dbaly V, et al. 2012. NovoTTF-100A versus physician's choice chemotherapy in recurrent glioblastoma: A randomised phase III trial of a novel treatment modality. Eur J Cancer 48: 2192-2202.

Sulzmaier FJ, Jean C, Schlaepfer DD. 2014. FAK in cancer: Mechanistic findings and clinical applications. Nat Rev Cancer 14: 598-610.

Sun Y, Campisi J, Higano C, Beer TM, Porter P, Coleman I, True L, Nelson PS. 2012. Treatment-induced damage to the tumor microenvironment promotes prostate cancer therapy resistance through WNT16B. Nat Med 18: 13591368.

Swanson KD, Lok E, Wong ET. 2016. An overview of alternating electric fields therapy (NovoTTF therapy) for the treatment of malignant glioma. Curr Neurol Neurosci Rep 16: 8 .

Tavora B, Reynolds LE, Batista S, Demircioglu F, Fernandez I, Lechertier T, Lees DM, Wong PP, Alexopoulou A, Elia G, et al. 2014. Endothelial-cell FAK targeting sensitizes tumours to DNA-damaging therapy. Nature 514: 112-116.

Topalian SL, Drake CG, Pardoll DM. 2015. Immune checkpoint blockade: A common denominator approach to cancer therapy. Cancer Cell 27: 450-461.

Tsai KK, Stuart J, Chuang YY, Little JB, Yuan ZM. 2009. Lowdose radiation-induced senescent stromal fibroblasts render nearby breast cancer cells radioresistant. Radiat Res 172: $306-313$.

Vander Heiden MG, Cantley LC, Thompson CB. 2009. Understanding the Warburg effect: The metabolic requirements of cell proliferation. Science 324: 1029-1033.

Vanpouille-Box C, Diamond JM, Pilones KA, Zavadil J, Babb JS, Formenti SC, Barcellos-Hoff MH, Demaria S. 2015. TGF $\beta$ is a master regulator of radiation therapyinduced antitumor immunity. Cancer Res 75: $2232-$ 2242.

Wang W, Li Q, Yamada T, Matsumoto K, Matsumoto I, Oda M, Watanabe G, Kayano Y, Nishioka Y, Sone S, et al. 2009 Crosstalk to stromal fibroblasts induces resistance of lung cancer to epidermal growth factor receptor tyrosine kinase inhibitors. Clin Cancer Res 15: 6630-6638.

Wculek SK, Malanchi I. 2015a. Neutrophils fan cancer's flames. EMBO J 34: 2211-2212.

Wculek SK, Malanchi I. 2015b. Neutrophils support lung colonization of metastasis-initiating breast cancer cells. Nature 528: 413-417.

Wilson TR, Fridlyand J, Yan Y, Penuel E, Burton L, Chan E, Peng J, Lin E, Wang Y, Sosman J, et al. 2012. Widespread potential for growth-factor-driven resistance to anticancer kinase inhibitors. Nature 487: 505-509.

Wong PP, Demircioglu F, Ghazaly E, Alrawashdeh W, Stratford MR, Scudamore CL, Cereser B, Crnogorac-Jurcevic T, McDonald S, Elia G, et al. 2015. Dual-action combination therapy enhances angiogenesis while reducing tumor growth and spread. Cancer Cell 27: 123-137.

Yarnold J, Brotons MC. 2010. Pathogenetic mechanisms in radiation fibrosis. Radiother Oncol 97: 149-161.

Zhang XH, Jin X, Malladi S, Zou Y, Wen YH, Brogi E, Smid M, Foekens JA, Massague J. 2013. Selection of bone metastasis seeds by mesenchymal signals in the primary tumor stroma. Cell 154: 1060-1073

Zhao X, Gao S, Ren H, Sun W, Zhang H, Sun J, Yang S, Hao J. 2014. Hypoxia-inducible factor-1 promotes pancreatic ductal adenocarcinoma invasion and metastasis by activating transcription of the actin-bundling protein fascin. Cancer Res 74: 2455-2464.

Zhao B, Sedlak JC, Srinivas R, Creixell P, Pritchard JR, Tidor B, Lauffenburger DA, Hemann MT. 2016. Exploiting temporal collateral sensitivity in tumor clonal evolution. Cell 165: 234-246. 


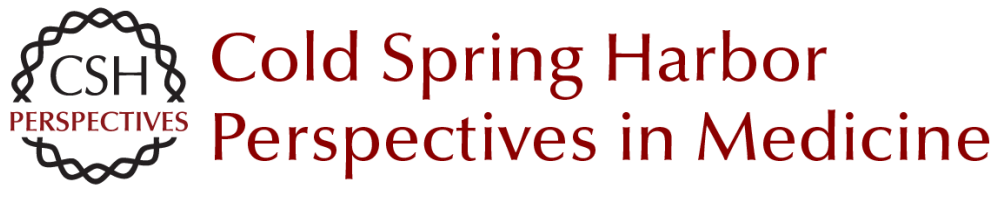

\section{Tumor Microenvironment and Differential Responses to Therapy}

Eishu Hirata and Erik Sahai

Cold Spring Harb Perspect Med 2017; doi: 10.1101/cshperspect.a026781 originally published online February 17, 2017

\section{Subject Collection Cancer Evolution}

The Evolution and Ecology of Resistance in Cancer Therapy Robert A. Gatenby and Joel S. Brown

Big Bang Tumor Growth and Clonal Evolution Ruping Sun, Zheng Hu and Christina Curtis

Observing Clonal Dynamics across

Spatiotemporal Axes: A Prelude to Quantitative

Fitness Models for Cancer

Andrew W. McPherson, Fong Chun Chan and

Sohrab P. Shah

Evolution of Premalignant Disease

Kit Curtius, Nicholas A. Wright and Trevor A. Graham

The Role of Aneuploidy in Cancer Evolution Laurent Sansregret and Charles Swanton

Treatment-Induced Mutagenesis and Selective Pressures Sculpt Cancer Evolution

Subramanian Venkatesan, Charles Swanton, Barry S. Taylor, et al.

Chromosomal Instability as a Driver of Tumor Heterogeneity and Evolution

Samuel F. Bakhoum and Dan Avi Landau

Coevolution of Leukemia and Host Immune Cells

in Chronic Lymphocytic Leukemia

Noelia Purroy and Catherine J. Wu
The Evolution and Ecology of Resistance in

Cancer Therapy

Robert Gatenby and Joel Brown

Phylogenetic Quantification of Intratumor

Heterogeneity

Thomas B.K. Watkins and Roland F. Schwarz

The "Achilles' Heel" of Cancer and Its Implications for the Development of Novel Immunotherapeutic Strategies

Kroopa Joshi, Benjamin M. Chain, Karl S. Peggs, et al.

Homeostasis Back and Forth: An Ecoevolutionary

Perspective of Cancer David Basanta and Alexander R.A. Anderson

Principles of Reconstructing the Subclonal

Architecture of Cancers

Stefan C. Dentro, David C. Wedge and Peter Van LOO

Tumor Microenvironment and Differential

Responses to Therapy

Eishu Hirata and Erik Sahai

Order Matters: The Order of Somatic Mutations Influences Cancer Evolution

David G. Kent and Anthony R. Green

The Cellular Origin and Evolution of Breast

Cancer

Mei Zhang, Adrian V. Lee and Jeffrey M. Rosen

For additional articles in this collection, see http://perspectivesinmedicine.cshlp.org/cgi/collection/ 